\title{
How is the Application and Design of a Product- Based Entrepreneurship Learning Tools in Vocational Higher Education?
}

\author{
Hendra Hidayat \\ Universitas Bung Hatta \\ Padang, Indonesia \\ hendrahidayat@bunghatta.ac.id
}

\begin{abstract}
This study aimed to produce entrepreneurial learning tools that are practical and effective for feasible use in the field. This research used the ADDIE development model, with research and development $(R \& D)$ method. Subjects of this research were students of Electrical Engineering in Vocational Higher Education who took entrepreneurship courses. The type of data was primary data which were given by expert lecturers and students. The instrument used to collect the data was a questionnaire. A descriptive data analysis technique was used to describe the practicality and effectiveness of product-based entrepreneurial learning tools. The results of this research are as follows: (1) a product-based learning tools, (2) based on the lecturers' response, the practicality of product-based entrepreneurial learning tools was considered practical $(87.14 \%)$ and based on the students' response, the practicality of the learning tools is $80.89 \%$, (4) the product-based entrepreneurial module is effective to improve students' learning outcomes $(20.38 \%)$. Based on research findings, it is concluded that the product-based entrepreneurial learning tools are practical and effective to be utilized as a learning tool in entrepreneurship courses
\end{abstract}

Keywords- Effectiveness; Entrepreneurial Learning Tools; Practicality

\section{INTRODUCTION}

Education, as a requirement for every citizen, has been arranged by each country. One of the formal educations in Indonesia is higher education, higher education functions to develop the competence and to build the characters and civilization of a dignified nation in order to educate the nation. Vocational education also prepares learners to be able to cope with changes in their communities. According to [1] states that "Vocational education should be responsive to the changes in society. In this era of rapid change of technology, vocational education must play many important roles in order to grabe roles in the world of work. "

The higher education, especially vocational education, certainly has education standards which have been set in the National Standards of Higher Education (SNPT). SNPT is a standard unit including the National Education Standards, the National Standards of Research, and the National Standard for Community Service. National Education Standards are the minimum criteria of learning in higher education in universities throughout the jurisdiction of the Unitary State of the Republic of Indonesia. All rules regarding SNPT are listed in the [2]. In addition, vocational education has also been listed in the Indonesian National Qualification Framework (KKNI), which is stated in the [3].

Learning in higher education is expected to be able to change the behavior and to develop students' competence as intelligent, comprehensive and characterized humans. The behavior changes and the development of these competencies must be in line with the standards competency of graduates that have been determined by the study program. The implementation of learning in universities should consider the following: (1) learning pillars of UNESCO "plus" which includes; learning to know, learning to do, learning to live together, and learning to be, and the last, learning to believe in God, (2) The core of education is learning, with the learning dimension in the form of: "from not knowing to know, from not able to be able," etc., (3) the learning content is expected to contain values: faith and piety, initiative (creative, sensitive and passionate), industrial (hard working, tenacious, high work ethic, disciplined, productive, etc.), individual differences (talents, interests, and motivations), and social and environmental interactions; and (4) learning outcomes (cognitive, affective, and psychomotor).

Almost all universities have entrepreneurship courses but not all of the graduates are capable in entrepreneurship, including the vocational graduates. Students who have graduated from college solely rely on their certificate and competences of their respective fields to find work, yet they cannot get a decent job. If these conditions continue to happen, the universities will contribute to educated unemployments. According to [4], based on the statistical data in August 2014, there are 9.5 percent $(688,660$ people) of the total unemployments who are alumni of colleges in Indonesia.

They have the certificate of diploma or undergraduate, or bachelor degree. Of that number, the highest number of unemployment, 495,143 people, is the university graduates who possess a bachelor degree. Those number (both those who have the certificate of diploma and bachelor) increases 
compared to in 2013, with the percentage of unemployed graduates of 8.36 percent $(619,288$ people) and in 2012 of 8.79 percent $(645,866$ people). This data show how college graduates still do not capable to compete in the labor market, one of the reason is because the learning process that occurs so far is still oriented to the target score.

Educated unemployment emerges due to various factors such as the lack of job opportunities, the rapid growth of universities and study programs, and the lack of competence possessed by graduates, or incompatibility with the needs of the labor users, and the ability to survive in communities with entrepreneurial competencies. The development of vocational education equipped with entrepreneurial competence is very crucial in overcoming educated unemployment both from nonvocational graduates and from vocational graduates. The process of vocational education in universities is not only a labor-maker and market-oriented but it is also expected that vocational graduates from universities are able to develop individual competencies in their entrepreneurship-based fields, which are expected to be able to produce many young technopreneurships. The formation of engineering entrepreneurs directly provides individual and economic improvement of the nation in general.

Based on field observations through the entrepreneurship lecturers, related to the subjects, there were some obstacles found in learning entrepreneurship, such as: (1) one factor that caused this course becomes less attractive was the lack of availability of practical and effective learning tools that could support the success of entrepreneurial learning process, (2) teaching materials used by lecturers during the learning process were entrepreneurial books that did not cover all basic competencies in the syllabus, (3) the learning process occurred in the entrepreneurship course still focused on the mastery of theory and the provision of skills that are not comprehensive, only in the form of exercises that did not lead students to generate a business plan, (4) the final task of entrepreneurship courses still did not describe the entire material explained.

Related to one of the obstacles encountered during observation, students are not yet be able to design a business plan that aims as a reference for students in opening a new business after finishing their study. This is certainly contrary to the learning outcomes of entrepreneurship courses. After attending entrepreneurship lectures, it is expected that each student is able to make a business plan as their provision to face the business world. The fact that occurred in the field is that the science from entrepreneurship learning process has not been implemented optimally. Based on the explanation of obstacles in entrepreneurship learning, the main reason to develop teaching tools in this research is that entrepreneurship courses in the faculty of engineering still do not have practical and effective learning tools in guiding students to be able to design a business plan to open new jobs which are based on their field. Therefore, it is necessary to develop a productbased learning tool in order to help the students to expand creative ideas easily during the entrepreneurship learning process.

Product-based learning tools can guide lecturers and students to produce business plan as the ultimate goal of the learning process. For one semester or 16 meetings, students under the guidance of lecturers, are required to be able to make the business plan activities they will undertake when they finish their studies.

The purpose of this study was to design and develop learning tools that are assumed to be able to help lecturers develop learning strategies in the effort to help students to be more creative. This research developed a product-based learning tool which was specifically designed for entrepreneurship learning. The use of product-based learning tools in learning was able to stimulate students to be more creative and independent in learning so they can increase the learning activities and learning outcomes. Based on the problems that have been described, this research becomes important as a solution of the problems in entrepreneurship courses.

\section{LITERATURE REVIEW}

\section{A. Product-Based Learning}

Product-based learning is a learning that facilitates students to be active and explore their potential and abilities, especially in vocational learning. These learning invites students to think critically produce a product that has benefits for the community and the industrial world. The need for appropriate products and services in the community becomes a high market demand, but does not have sufficient supply in the industry, this condition occurs because what is actually needed in the community has not been answered by the industry. Through product-based learning students are required to be creative and work together to produce products that have value to sell. Product-based learning is part of a production-based learning model [5]. In addition, this production-based learning model has also been tested to see entrepreneurial interest in universities especially in vocational education and it turns out there is an increase in entrepreneurial interest of students, not only interest but also student learning outcomes also seen the impact, followed by using business plan also seen impact Towards student learning outcomes [6], [7], [8], [9].

\section{B. Product-Based Entrepreneurship Learning Tool}

Product-Based Entrepreneurship Learning Tool is a learning plan designed to facilitate students to graduate after entrepreneurial competence. Entrepreneurial learning in vocational education is directed toward producing products and being able to plan business management and business planning. Product-based entrepreneurship learning planning in vocational education is the difference and added value of a higher education, because in this entrepreneurial learning the resulting product has commercial potential.

\section{RESEARCH METHODS}

Based on the background and formulation of the problem in this study, the type of research was research and development ( $\mathrm{R} \& \mathrm{D})$. This research includes to the research that produces products in the form of learning tools for entrepreneurship courses. The development model used was the ADDIE model. This research was focused on developing product-based entrepreneurial learning tools. This research 
was expected to overcome the problems that had been described in the background research.

The type of data used in the development of this productbased learning tool was the primary data. Data obtained from the trial were in the form of students' and lecturers' responses to learning tools developed after learning tools are tried out (practicality), and students' learning outcomes of cognitive aspects (effectiveness) which analyzed by using statistical formula.

The development procedure in this study followed the sequence of activities in the ADDIE model proposed by [10]. A more detailed description of the development procedure is described as follows:

\section{A. Analysis}

The analysis was conducted to identify the possibility of problems occurred in entrepreneurship learning through field surveys and literature studies. The analysis includes needs analysis such as curriculum analysis and student analysis. The results of the analysis could be used to develop a productbased entrepreneurial learning tool.

\section{B. Design}

In this stage, the form of problem-solving to be performed was verified and the appropriate testing method was determined. It includes the interpretation of the needs and learning objectives into the objectives of making specific learning tools. It also designed a product-based entrepreneurial learning tool in accordance with needs analysis. In addition, at this stage, it is also designed instruments to perform instrument validation of products, instruments of practicality, instrument effectiveness and instrument validation instrument.

\section{Development}

This development stage generated and validated a productbased entrepreneurial learning tool. The validation process was followed by a discussion or direct interview with the experts related to the improvements that must be done, that is by the design of the product-based learning tools consulted first to experts and mentors. Then, the design was assessed by the competent people (validator) who understood the principles of the development of learning tools, namely lecturers of vocational higher education entrepreneurship courses.

\section{Implementation}

Implementation stage was done by preparing the learning environment and students' involvement in the lecture consisting of the preparation of lecturers and students.

\section{E. Evaluation}

This stage assesses the quality of product development and development process both before and after implementation, by determining the evaluation criteria, determining the instrument and performing the evaluation.
The procedure of development and research can be seen in the following figure:

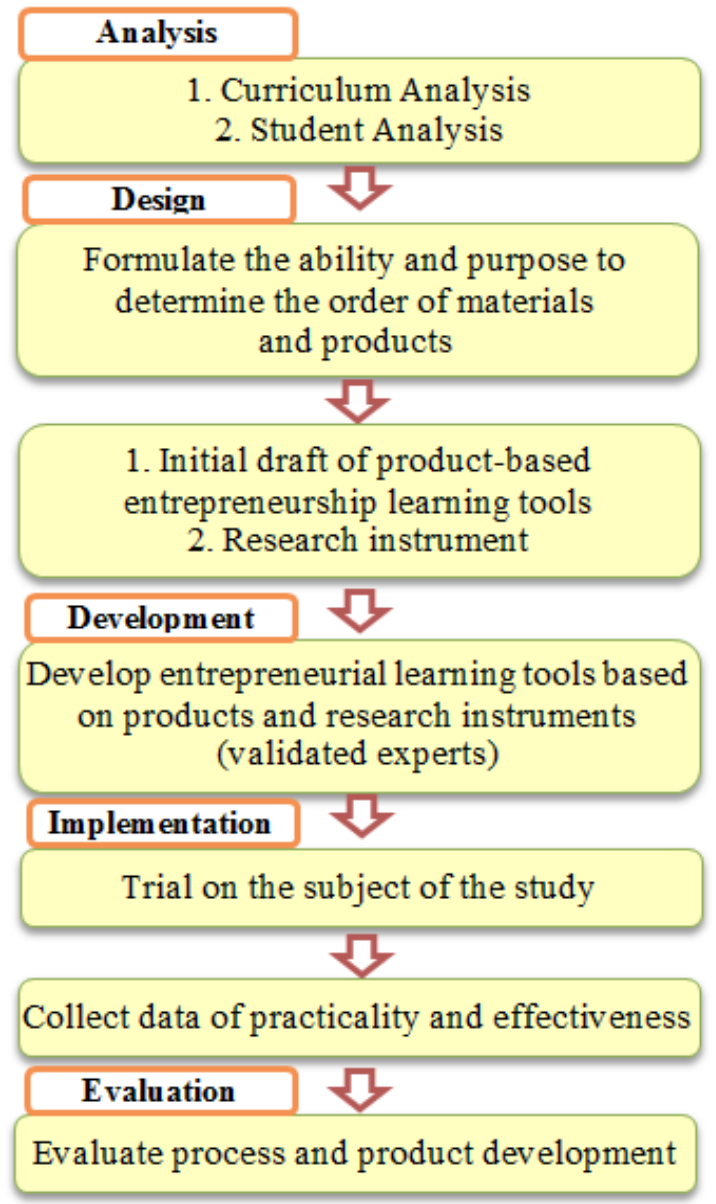

Figure 1. The implementation phase of the ADDIE model

The subjects of try out were students who were given entrepreneurship learning by using production-based learning tools. The subjects for the try out in developing productionbased learning tools were students in entrepreneurship subject of Electrical Engineering Education Study Program, the Faculty of Engineering, Higher Education.

The research instruments used to collect data in this research were as follows; (1) the practicality sheet, This Practical Instrument was used to obtain data on the level of the use of learning tool. It consists of the product practicality level for lecturers and students which were described by using the Likert Scale. The stages to set up the practicality sheet were similar to the stages to set up the validation sheets. (2) Effectiveness sheets. Effectiveness instruments were used to collect the effectiveness data. These instruments were the instruments of learning outcome assessment. Learning outcomes were obtained by giving students a test on a class that had been given learning treatment by using valid and practical learning tools. The test used to obtain students' learning outcomes was a cognitive test in the form of multiple 
choices that was conducted at the end of learning after using production-based learning tools.

\section{RESULTS AND DISCUSSION}

Based information and an overview of the analysis of the needs of the initial conditions that produced the stage entrepreneurial learning based products; the design consists of 16 sessions as follows:

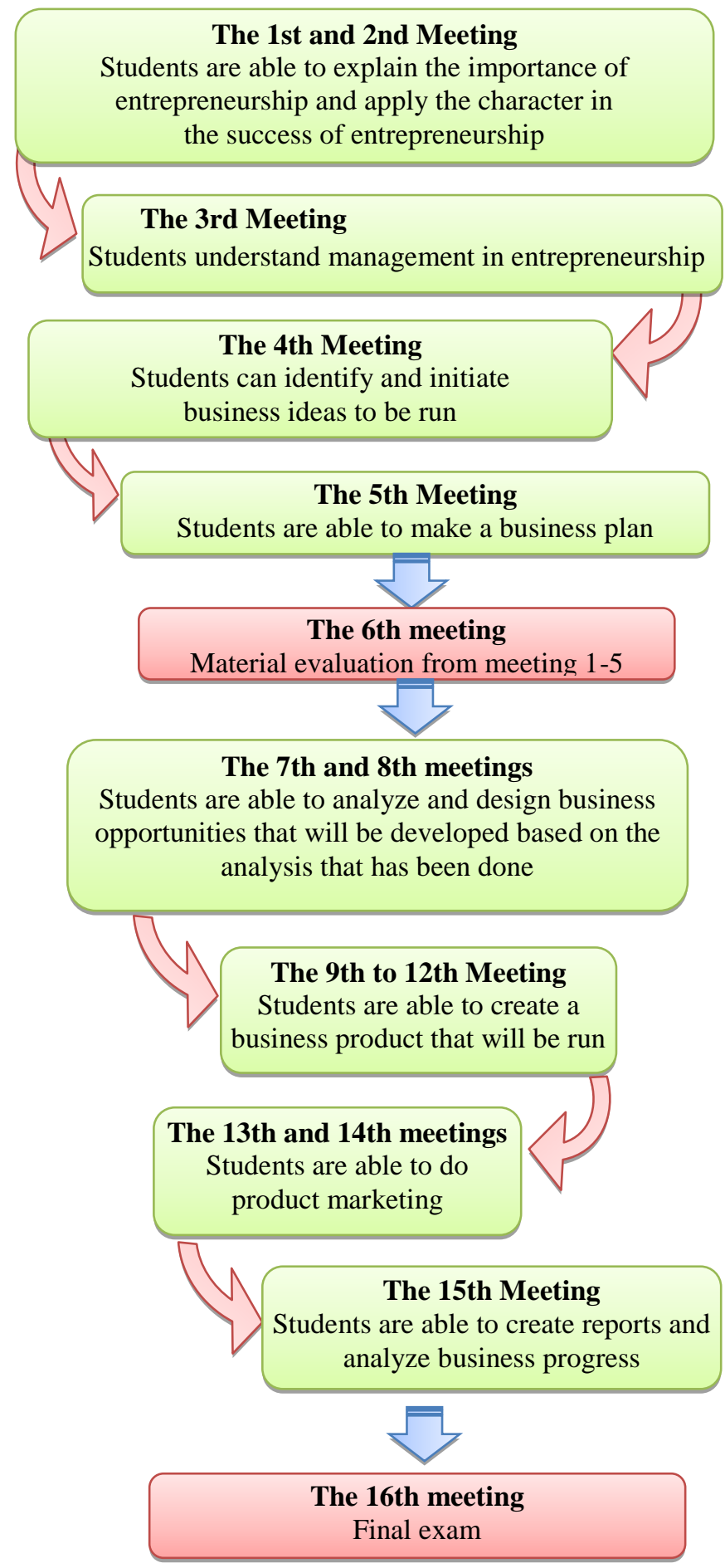

Figure 2. The stage entrepreneurial learning based products
Product-based entrepreneurial learning tools are designed to enhance students' creativiity skills, in which students are directed to be able to make a business plan at the end of the learning process. This learning tool consists of the development of Semester Learning Plan (RPS) and Learning Evaluation Unit (SAP). Learning tools are developed in accordance with the curriculum of Entrepreneurship courses for Electrical Engineering students of Faculty of Engineering.

The development of product-based learning tools was done by using the development model of ADDIE, in which the development stage are as follows:

\section{A. Analysis}

At this stage, the researchers conducted several activities, namely: curriculum analysis and student analysis. This stage was done as a basis for developing product-based entrepreneurial learning tools so that it can be used either by lecturers or students in the learning process, in which the development of this product was adjusted to the needs of the curriculum and students.

\section{B. Design}

At the planning stage, the researchers designed the product-based entrepreneurial learning tools. This product was made in accordance with product specifications that had been designed, manufactured, validated and also tried out. At this stage, researchers designed the product-based learning tools on learning entrepreneurship (fig.2).

\section{Developping and Implementation Stage}

\section{The Practical Test of Product-Based Learning Tools}

Having obtained valid product results, the results of practicality test for product-based learning tools given to lecturers and students through questionnaire responses shows that the level of practicality can be categorized as practical. Questionnaires of lecturers were given to 2 lecturers to see the their response in the practicality of the use of product-based entrepreneurial learning tools. Meanwhile, the questionnaires of students were given to 20 students to see the practicality of using these learning tools.

The result of practicality test of learning device given to the lecturers was $87,14 \%$ in average which can be categorized as practical. These results indicate that the product-based learning tools developed facilitate lecturers in helping students to learn independently and assist lecturers in understanding the concept of learning materials.

The result of practicality of product-based learning tools based on student response was $80.89 \%$ in average with practical category. These results suggest that product-based learning tools developed with practical categories can facilitate students in understanding materials.

Beside that every educator in the educational unit is obliged to formulate learning tools that take place interactively, Inspiratively, and fun, and motivate the students to participate actively. Learning tools can improve students' creativity skills because students are directed to be able to make a business plan at the end of the learning process. 


\section{The Practical Test of Product-Based Learning Tools}

The effectiveness of learning tools in this study can be seen from the ability of learning tools to improve students' creativity and facilitate lecturers in delivering the learning materials. The use of learning tools will greatly help the effectiveness of the learning process and delivery of messages at that time. In addition to improving the learning activities, learning tools can also help students improve their understanding.

The effectiveness of learning tools in this study was investigated from students' learning outcomes. The effectiveness of learning outcomes of the use of product-based learning tools was done with two types of tests that were pretest and posttest; the pretest was done before the students were treated by using product-based learning tools with the average score of 61.54 , while posttest was done after students were treated by using the product-based learning tools with the average score of 81.92 . Based on this result, it can be concluded that the product-based learning tools developed by researchers was effective to be used to improve student learning outcomes.

According to [11], effectiveness refers to the level of the intervention experiences and outcomes. The effectiveness of product-based learning tools can be seen from the results of student learning who are directly involved in the learning process. Based on the development stage above, it can be concluded that this product-based learning tool is one of the learning tool that is valid, practical and effective to be implemented in the learning process for Entrepreneurship courses in Electrical Engineering Education Study Program

\section{Evaluation}

Evaluation at this stage is done final examination.

\section{Application and impact on higher education vocational,}

The mission of vocational education in high education as the agent of change and the motor of the economy of society. The role of vocational education in higher education is very strategic especially for higher education that seriously develop the direction of the campus into entrepreneurship-based campus is no longer teaching and research university. Of course, a heavy duty and responsibility is to change the mindset of the campus community, so that with the planning of entrepreneurship-based learning products will be the embryo of the birth of entrepreneurship university. The future challenge is how to cultivate students' learning ability that is capable of creative, high thinking and problem solving thinking. This product-based entrepreneurship learning planning has 16 meetings, starting with curriculum analysis phase, understanding entrepreneurship management, making business planning, product making, business planning report and evaluation.

\section{CONCLUSION}

This study is a research of the development of productbased entrepreneurial learning tools. Based on the result of the research, it can be concluded that:
A. The development of Entrepreneurial learning tools used the ADDIE model, which consists of analysis, design, development and evaluation. This entrepreneurship module consists of nine learning topics: the first topic deals with introductory entrepreneurship; the second topic on entrepreneurial spirit, third topic on the role of management in entrepreneurship, fourth topic on accounting, fifth topic on fund management, sixth topic on production management, seventh topic Marketing management, the eighth topic on human resource management, and the ninth topic of business planning.

$B$. The development of this learning tool produces practical and effective tool. The practicality of learning tools assessed based on lecturers' responses is practical $(87.14 \%)$. While practicality based on student response is also categorized as practical $(80.89 \%)$. The effectiveness test is seen from student learning outcomes. Learning outcomes for entrepreneurial learning show that the average learning outcome of 20 students who took the test before they used product-based modules was 61.54 , which was categorized as fairly effective. After they used product-based modules, the average learning outcomes was 81.92, this is an effective category. According to Sudijono Anas, if students' learning outcomes are in the range of 81-100, it can be categorized as very effective.

From the result of this study, it is suggested as the following:

A. For other researchers, it is expected to do the development of similar things on learning materials, both on Entrepreneurship subjects and other subjects.

$B$. For Lecturers, it is hope they can use Entrepreneurial learning tools as a supporting medium of learning.

C. For Students, after using entrepreneurial learning tools, it is expected to be more active so as to encourage selfpotential in improving learning outcomes and at the end of learning can produce a business plan that will be implemented.

$D$. For further research, it is suggested to use this learning tool to direct students to make a business plan and to implement the business plan that has been made.

\section{ACKNOWLEDGMENT}

The authors wish to thank all who have helped materialize this study. All the universities and stakeholders were who support the successful of this study, especially to the department of electrical engineering, faculty of engineering in higher education who has facilitated this research. In addition, all the administrative staff who assist the course of research.

\section{REFERENCES}

[1] Jama, Jalius. 2010. Transformasi Teknologi pada Pendidikan Kejuruan. Makalah Seminar Internasional. Aptekindo. Padang. Unpublished 
[2] Regulation of the Minister of Research, Technology and Higher Education (Permenristekdikti) number 44 of 2015 about National Standards of Higher Education

[3] Regulation of the Minister of Education and Culture (Permendikbud) No. 73 of 2013

[4] Setiawan, Iwan. 2015. Ijazah Saja Kini Tak Cukup Lagi. Kompas.com, http://edukasi.kompas.com/read/2015/02/04/12590071/Ijazah.Saja.Kini. Tak.Cukup.Lagi

[5] Ganefri and Hidayat, Hendra. 2014. Production based Learning: An Instructional Design Model in the Context of Vocational Education and Training (VET). Global Journal of Science Frontier Research (GJSFR), 14(3).1-6

[6] Ganefri , Hendra Hidayat, Indrati Kusumaningrum, Mega Silfia Dewy and Sartika Anori, 2017. Learning Outcomes in Vocational Study: A Development of Product Based Learning Model. The Social Sciences, 12: $831-838$.
[7] Kusumaningrum I; Ganefri; \& Hendra Hidayat. 2015. Improving Students' Entrepreneurial Interest using Production Based Learning Model in TVET. Advances in Social Science, Education and Humanities Research (ASSEHR). 14(2015), 69-74. doi:10.2991/ictvet-14.2015.17.

[8] Kusumaningrum, I., Hidayat, Hendra., Ganefri, , Anori, S. \& Dewy, M.S. 2016. Learning Outcomes in Vocational Education: a Business Plan Development by Production-Based Learning Model Approach. International Journal of Environmental and Science Education, 11(18), 11917-11930.

[9] Hidayat, Hendra. 2017. Impact of Learning with the Production Based Learning Model in Vocational Education. International Journal of Research in Engineering and Social Sciences, 7 (2), 1-6.

[10] Branch, Robert M. 2009. Instructional Design: The ADDIE Approach. New York: Springer Science Business Media, LLC.

[11] Akker. 1999. Design Approaches and Tools in Education and Training. Dordrecht: Kluwer Academic Publishers 